\title{
Kompetensi, Beban Kerja dan Kualitas Penyajian Laporan Keuangan di UPT Kementerian LHK Bali
}

\author{
Nyoman Ari Widnyani ${ }^{1}$ \\ Fakultas Ekonomi dan Bisnis \\ Universitas Udayana, Indonesia
}

\author{
A.A.G.P. Widanaputra ${ }^{2}$ \\ Fakultas Ekonomi dan Bisnis \\ Universitas Udayana, Indonesia
}

\begin{abstract}
Surel : ariwidnyani98@gmail.com
ABSTRAK

Penelitian ini dilakukan untuk mengetahui pengaruh kompetensi dan beban kerja pada kualitas penyajian laporan keuangan. Penelitian ini dilakukan di 8 UPT Kementerian Lingkungan Hidup dan Kehutanan Provinsi Bali. Penentuan sampel dengan menggunakan nonprobability sampling yaitu dengan pendekatan purposive sampling. Metode pengumpulan data dalam penelitian ini dengan menggunakan kuesioner yang diberikan kepada KPA, Bendahara dan Operator SAI di masing-masing satuan kerja dengan total keseluruhan 40 kuesioner. Teknik analisis yang digunakan adalah analisis regresi linier berganda. Hasil penelitian ini menggambarkan bahwa kompetensi berpengaruh positif signifikan terhadap kualitas penyajian laporan keuangan artinya semakin tinggi kompetensi yang dimiliki maka semakin meningkat pula kualitas penyajian laporan keuangan, sedangkan beban kerja berpengaruh negatif signifikan terhadap kualitas penyajian laporan keuangan artinya semakin tinggi beban kerja yang dimiliki pegawai maka kualitas penyajian laporan keuangan akan semakin menurun.
\end{abstract}

Kata Kunci: Kompetensi; Beban Kerja; Kualitas Penyajian Laporan Keuangan.

\section{Competence, Workload and Quality of Financial Report Presentation at the UPT Ministry of LHK Bali}

\section{ABSTRACT}

This research was conducted to determine the effect of competence and workload on the quality of financial statement presentation. This research was conducted at 8 UPT Ministry of Environment and Forestry in Bali Province. Determination of the sample using nonprobability sampling is the purposive sampling approach. The analysis technique used is multiple linear regression analysis. The results of this study illustrate that competence has a significant positive effect on the quality of the presentation of financial statements, meaning that the higher the competency possessed, the quality of financial statement presentation increases, while the workload has a significant negative effect on the quality of the presentation of financial statements, meaning that the higher the workload of employees the presentation of financial statements will continue to decline.

Keywords: $\quad$ Competence; Workload; Quality of Financial Statement Presentation.

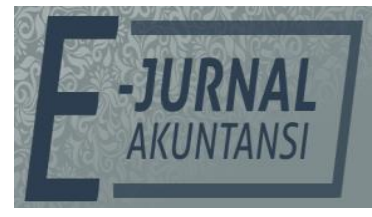

e-ISSN 2302-8556

Vol. 31 No. 1

Denpasar, Januari 2021

Hal. 220-232

DOI:

10.24843/EJA.2021.v31.i01.p17

PENGUTIPAN:

Widnyani, N. A., \& Putra, A.A.G.P. (2021). Kompetensi, Beban Kerja dan Kualitas Penyajian Laporan Keuangan di UPT Kementerian LHK Bali. EJurnal Akuntansi, 31(1), 220-

232

RIWAYAT ARTIKEL: Artikel Masuk: 25 Mei 2020 Artikel Diterima: 4 Januari 2021

Artikel dapat diakses : https://ojs.unud.ac.id/index.php/Akuntansi/index 


\section{PENDAHULUAN}

Standar Akuntansi Pemerintahan (SAP) paragraf 26 menyatakan bahwa tujuan laporan keuangan pemerintah adalah untuk menyajikan informasi yang bermanfaat bagi para pengguna dalam menilai akuntabilitas dan membuat keputusan baik keputusan ekonomi, sosial, maupun politik dengan: a) menyediakan informasi mengenai sumber, alokasi dan penggunaan sumber daya keuangan; b) menyediakan informasi mengenai jumlah sumber daya ekonomi yang digunakan dalam kegiatan entitas pelaporan serta hasil-hasil yang telah dicapai; c) menyediakan informasi mengenai bagaimana entitas pelaporan mendanai seluruh kegiatannya dan mencukupi kebutuhan kasnya; d) menyediakan informasi mengenai posisi keuangan dan kondisi entitas pelaporan berkaitan dengan sumber-sumber penerimaannya, baik jangka pendek maupun jangka panjang, termasuk yang berasal dari pungutan pajak dan pinjaman; e) menyediakan informasi mengenai perubahan posisi keuangan entitas pelaporan, apakah mengalami kenaikan atau penurunan, sebagai akibat kegiatan yang dilakukan selama periode pelaporan. Banyaknya informasi yang tersedia dalam laporan keuangan pemerintah tersebut menunjukkan bahwa kualitas penyajian laporan keuangan menjadi penting agar tidak menyebabkan misleading bagi para penggunanya.

Laporan keuangan kementerian/lembaga dihasilkan melalui Sistem Akuntansi Instansi (SAI). Sistem Akuntansi Instansi dirancang untuk menghasilkan laporan keuangan kementerian/lembaga yang terdiri atas Laporan Realisasi Anggaran (LRA), Neraca, dan Catatan atas Laporan Keuangan (CALK), sedangkan Sistem Informasi Manajemen dan Akuntansi Barang Milik Negara (SIMAK-BMN) adalah sistem yang menghasilkan informasi aset tetap, persediaan, dan lainnya untuk penyusunan neraca dan laporan barang milik negara. Laporan keuangan kementerian/lembaga dapat diuji keandalannya dengan laporan keuangan yang dihasilkan oleh unit kerja melalui proses rekonsiliasi. Proses rekonsiliasi adalah proses pencocokan data transaksi keuangan yang diproses dengan sistem yang berbeda berdasarkan dokumen sumber yang sama sehingga menghasilkan data yang akurat dan handal Sistem Akuntansi Instansi saat ini sangat besar pengaruhnya terhadap laporan keuangan, karena sanksi keterlambatan penyampaian laporan keuangan bagi instansi berdampak buruk bagi kinerja instansi dimasa mendatang. Pengaruh kinerja dimaksud adalah apabila Kuasa Pengguna Anggaran (KPA) yakni satuan kerja terlambat atau tidak menyampaikan laporan keuangan tersebut, KPPN dapat menunda penerbitan Surat Perintah Pencairan Dana (SP2D) atas Surat Perintah Membayar (SPM) yang diajukan oleh satuan kerja. Prestasi dalam penyampaian laporan keuangan yang menyangkut ketepatan waktu dan keakuratan data dapat tidak terpenuhi.

UPT Kementerian Lingkungan Hidup dan Kehutanan daerah Provinsi Bali terdiri dari 8 satuan kerja terdiri dari Pusat Pengendalian Pembangunan Ekoregion Bali Nusra, Balai Konservasi Sumber Daya Alam Bali, Balai Pemantapan Kawasan Hutan Wilayah VIII Denpasar, Balai Pengelolaan Hutan Produksi Wilayah VII Denpasar, Balai Pengendalian Perubahan Iklim dan Kebakaran Hutan dan Lahan Wilayah Jabalnusra, Balai Perhutanan Sosial dan 
Kemitraan Lingkungan Wilayah Jabalnusra, Balai Taman Nasional Bali Barat dan Balai Pengendalian Daerah Aliran Sungai dan Hutan Lindung Unda Anyar.

UPT Kementerian Lingkungan Hidup dan Kehutanan lingkup Provinsi Bali selain melaksanakan fungsi teknis juga menjalankan tugas serta pelayanan administrasi perkantoran. Pengelolaan pertanggungjawaban dan pengelolaan keuangan di satuan kerja Kementerian Lingkungan Hidup dan Kehutanan berada di subbidang keuangan dan perlengkapan. Pada masing-masing pegawai di subbidang keuangan dan perlengkapan telah dilakukan pembagian kerja sesuai dengan tugas pokok dan fungsinya. Namun masih ada pegawai yang memiliki beban kerja ganda secara terus menerus. Salah satunya penyusun laporan keuangan yaitu operator SAI. Operator SAI ada yang merangkap tugas sebagai bendahara pengeluaran, fungsional, bendahara penerimaan, operator aplikasi Rencana Kerja dan Anggaran Kementerian Negara/Lembaga (RKAKL), operator persediaan, uang makan dan pembuat daftar gaji (PDG). Banyak dari operator SAI di satuan kerja yang memiliki beban kerja berlebih, terlihat dari rangkap pekerjaan yang hanya dilakukan oleh satu orang.

Kompleksitas tugas penyusun laporan keuangan mengakibatkan keterlambatan pelaporan dan pertanggungjawaban keuangan khususnya proses rekonsiliasi dengan KPPN setempat sebagai dasar penyusunan laporan keuangan. Sesuai dengan Peraturan Menteri Keuangan No.210/PMK.05/2013 pasal 11 tentang sanksi atas keterlambatan penyampaian laporan keuangan ke KPPN, menyebutkan bahwa penyampaian laporan keuangan paling lambat tanggal 10 setelah bulan bersangkutan berakhir.

Menurut Undang-Undang Nomor 7 Tahun 2013 Tentang Pedoman Penyusunan Standar Kompetensi Manjerial Pegawai Negeri Sipil, kompetensi merupakan kemampuan yang dimiliki seseorang berupa pengetahuan, keterampilan dan sikap yang dibutuhkan dalam melaksanakan suatu tugas. Sehubungan dengan hal tersebut, diperlukan kompetensi penyusun laporan keuangan untuk menyajikan laporan keuangan yang berkualitas. Kompetensi merupakan ciri seseorang yang dapat dilihat dari keterampilan, pengetahuan dan kemampuan yang dimilikinya dalam hal menyelesaikan tugas-tugas yang dibebankan kepadanya. Dengan adanya kompetensi sumber daya manusia maka waktu pembuatan laporan keuangan dapat efisien, karena sumber daya manusia tersebut telah memiliki pengetahuan dan pemahaman mengenai hal-hal yang dikerjakan sehingga laporan keuangan yang disusun dapat diselesaikan dan disajikan tepat pada waktunya. Semakin cepat laporan keuangan disajikan maka akan semakin baik dalam hal pengambilan keputusan (Mardiasmo, 2002).

Menurut Menteri Pendayagunaan Aparatur Negara (1997), beban kerja adalah sekumpulan atau sejumlah kegiatan yang harus diselesaikan oleh suatu organisasi atau pemegang jabatan dalam jangka waktu tertentu. Beban kerja yang meningkat akan berpengaruh pada penurunan kemampuan kerja pegawai yang akibatnya kualitas kerja pegawai sangat rendah dalam menyelesaikan suatu pekerjaan. Namun apabila pengelolaan beban kerja yang baik dan pembagian job description yang disesuaikan dengan kemampuan kerja pegawai serta diimbangi berupa pengetahuan dan keterampilan dalam menyelesaikan pekerjaan maka beban kerja yang dirasakan bisa diminimalkan karena adanya 
kecepatan dan kecakapan dalam menyelesaikan suatu pekerjaan (Suma'mur, 1995).

Kualitas penyajian laporan keuangan tidak terlepas dari perilaku penyusun laporan keuangan tersebut. Dalam penelitian yang di kembangkan oleh Donaldson (1997) menyatakan bahwa Teori pengelolaan (Stewardship theory) menggambarkan situasi dimana manajemen tidaklah termotivasi oleh tujuantujuan individu tetapi lebih ditujukan pada sasaran hasil utama untuk kepentingan organisasi. Teori tersebut mengasumsikan adanya hubungan yang kuat antara kepuasan dan kesuksesan organisasi. Perilaku penyusun laporan keuangan ditentukan oleh sikap, aturan-aturan, kebiasaan dan konsekuensinya dalam menyelesaikan dan menyajikan laporan keuangan tepat pada waktunya. Penyusun laporan keuangan yang memiliki kompetensi dapat dilihat dari perilakunya seperti disiplin dalam bekerja, taat pada peraturan yang berlaku, bertanggungjawab dalam pekerjaannya dan sebagainya.

Teori pengelolaan (Stewardship theory) dikembangkan oleh Davis, J.H., Schoorman, D.L. \& Donaldson (1997) dapat dijadikan teori yang mendasari untuk menjelaskan kompetensi. Asumsi filosofi mengenai stewardship theory dibangun berdasarkan sifat manusia yaitu dapat dipercaya, mampu bertindak dengan penuh tanggung jawab, memiliki integritas, serta dapat berlaku jujur untuk pihak lainnya dalam menyelesaikan tugas yang diberikan oleh pengelola sesuai dengan kompetensi yang dimiliki. Kualitas penyajian laporan keuangan tidak terlepas dari perilaku penyusun laporan keuangan tersebut. Perilaku penyusun laporan keuangan ditentukan oleh sikap, aturan-aturan, kebiasaan dan konsekuensinya dalam menyelesaikan dan menyajikan laporan keuangan tepat pada waktunya. Asumsi dasar teori stewardship, yaitu model manusia, berperilaku kolektif untuk kepentingan organisasi (Podrug, 2011). Prinsip stewardship theory, yaitu pemberdaya pegawai melalui responsibilitas, otonomi, budaya, dan norma-norma bersama, serta kekuatan pribadi dan kepercayaan (Slyke, 2006).

Sikap dan perilaku penyusun laporan keuangan berbeda-beda, ini dipengaruhi kompetensi dari penyusun laporan keuangan tersebut. Kompentensi penyusun laporan keuangan sangat diperlukan karena kompetensi merupakan dasar seseorang untuk mencapai kinerja tinggi dalam menyelesaikan kinerjanya. Dengan adanya sumber daya manusia yang kompeten maka waktu pembuatan laporan keuangan dapat efesien, karena sumber daya manusia tersebut telah memiliki pengetahuan dan pemahaman mengenai hal-hal yang dikerjakan sehingga laporan keuangan yang disusun dapat diselesaikan dan disajikan tepat pada waktunya. Hal ini sejalan dengan penelitian (Rahman et al., 2012) menyatakan bahwa kompetensi, pelatihan dan SAI berpengaruh positif terhadap kualitas laporan keuangan. Berdasarkan uraian di atas semakin tinggi kompetensi operator SAI maka kualitas penyajian laporan keuangan akan semakin tinggi, maka disusun hipotesis sebagai berikut.

$\mathrm{H}_{1}$ : Kompetensi operator SAI berpengaruh positif pada kualitas penyajian laporan keuangan.

Teori pengelolaan (Stewardship theory) dikembangkan oleh (Davis, J. H., Schoorma, F. D., \& Donaldson, 1997) dapat dijadikan teori yang mendasari untuk menjelaskan beban kerja. Pada awal perkembangannya, akuntansi organisasi 
sektor publik bermanfaat untuk memenuhi kebutuhan informasi antara stewards dengan principals. Terdapat spesialisasi dalam akuntansi serta perkembangannya dalam organisasi sektor publik, selaku principals sangat sulit untuk melakukan sendiri fungsi-fungsi pengelolaan. Pemisahan antara fungsi kepemilikan dengan fungsi pengelolaan sangat jelas.

Dengan adanya keterbatasan, pemilik sumber daya menyerahkan amanah pengelolaan sumber daya kepada pihak lain (stewards/manajemen) yang lebih siap. Kontrak hubungan antara principals dengan stewards didasari dengan kepercayaan, kolektif sesuai dengan tujuan organisasi. Kebiasaaan berkaitan dengan apa yang biasa mereka lakukan dan konsekuensi merupakan akibat dari perilaku yang dipikirkan. Beban kerja yang berlebih dapat mempengaruhi sikap dan perilaku dari penyusun laporan keuangan yang akibatnya kualitas kerja menurun. Tingginya beban kerja (workload) seorang operator SAI, yang mana operator SAI memiliki banyak tugas yang harus diselesaikan sedangkan waktu yang dimiliki terbatas maka operator SAI akan cenderung menerima penjelasan dan tidak lebih fokus dalam mengenai laporan keuangan yang diperolehnya. Hal ini sejalan dengan penelitian (Lopez-Acevedo, 2005) bahwa proses audit yang dilakukan ketika ada tekanan workload akan menghasilkan kualitas audit yang lebih rendah dibandingkan dengan ketika tidak ada tekanan workload. Berdasarkan uraian di atas semakin tinggi beban kerja operator SAI maka kualitas penyajian laporan keuangan akan semakin rendah, maka disusun hipotesis sebagai berikut.

$\mathrm{H}_{2}$ : Beban kerja operator SAI berpengaruh negatif pada kualitas penyajian laporan keuangan.

\section{METODE PENELITIAN}

Penelitian ini dilaksanakan pada satuan kerja UPT Kementerian Lingkungan Hidup dan Kehutanan Lingkup Provinsi Bali terdiri dari 8 satuan kerja terdiri dari P3E Bali Nusra, BKSDA Bali, BPKH Wilayah VIII Denpasar, BPHP Wilayah VII Denpasar, PPI Jawa Bali Nusa Tenggara, PSKL Jawa Bali Nusa Tenggara, BTN Bali Barat dan BPDAS Unda Anyar. Objek penelitian ini adalah kualitas penyajian laporan keuangan di UPT Kementerian Lingkungan Hidup dan Kehutanan yang dipengaruhi oleh kompetensi dan beban kerja. Data diperoleh dari kuesioner yang disebar ke UPT Kementerian Lingkungan Hidup dan Kehutanan Provinsi Bali.

Populasi dalam penelitian ini adalah ASN (Aparatur Sipil Negara) pada satuan kerja UPT Kementerian Lingkungan Hidup dan Kehutanan Provinsi Bali yaitu pengelola keuangan yang menghasilkan laporan keuangan masing-masing satuan kerja.

Teknik penentuan sampel dalam penelitian ini adalah nonprobability sampling yaitu dengan pendekatan purposive sampling. Nonprobability sampling adalah teknik pengambilan sampel yang tidak memberi peluang atau kesempatan sama bagi setiap unsur atau anggota populasi untuk dipilih menjadi sampel (Sugiyono, 2015). Purposive sampling merupakan teknik penentuan sampel dengan pertimbangan tertentu (Sugiyono, 2015). Kriteria yang digunakan dalam penelitian ini adalah operator SAI yang terdiri dari operator SAIBA (Sistem Aplikasi Instansi Basis Akrual) dan operator SIMAK-BMN (Sistem 
Informasi Manajemen dan Akuntansi Barang Milik Negara), Kuasa Pengguna Anggaran, serta Bendahara pada satuan kerja UPT Kementerian Lingkungan Hidup dan Kehutanan Provinsi Bali yang bertanggung jawab terhadap penyajian laporan keuangan di masing-masing satuan kerja. Sampel yang diteliti adalah yang ikut serta dalam penyusunan pelaporan keuangan sehingga dapat memberikan informasi kepada peneliti, tentang sejauh mana operator SAI secara keseluruhan dengan melakukan pengujian terhadap tiga faktor yaitu: Kompetensi, Beban Kerja dan Kualitas Penyajian Laporan Keuangan.

Teknik analisis data yang digunakan dalam penelitian ini adalah analisis regresi linear berganda dengan bantuan program SPSS for windows. Analisis regresi linear berganda menunjukkan pengaruh hubungan antara variabel independen terhadap variabel dependen dengan persamaan sebagai berikut.

$Y=\alpha+\beta_{1} X_{1}+\beta_{2} X_{2}+\varepsilon$

Keterangan:

$\mathrm{Y} \quad=$ Kualitas Penyajian Laporan Keuangan

a $\quad=$ Konstanta

$\beta_{1} \quad=$ Koefisien regresi kompetensi

$\beta_{2} \quad=$ Koefisien regresi beban kerja

$\mathrm{X}_{1} \quad=$ Kompetensi

$\mathrm{X}_{2} \quad=$ Beban Kerja

$\varepsilon \quad=$ error terms

\section{HASIL DAN PEMBAHASAN}

Statistik deskriptif dalam penelitian ini disajikan untuk memberikan informasi tentang karakteristik variabel penelitian. Nilai minimum menunjukkan nilai terkecil atau terendah pada suatu gugus data. Nilai maksimum menunjukkan nilai terbesar atau tertinggi pada suatu gugus data. Rata-rata (noun) merupakan cara yang paling umum digunakan untuk mengukur nilai sentral dari suatu distribusi data yang diteliti. Deviasi standar adalah ukuran yang menunjukkan standar penyimpangan data observasi terhadap rata-rata datanya. Adapun hasil statistik deskriptif pada penelitian ini yang dapat dilihat pada Tabel 1, sebagai berikut.

\section{Tabel 1. Statistik Deskriptif}

\begin{tabular}{lrrrrl}
\hline Variabel & $\mathrm{N}$ & Min. & Max. & Mean & $\begin{array}{l}\text { Std. } \\
\text { Deviation }\end{array}$ \\
\hline Kompetensi & 40 & 43.00 & 60.00 & 50.9000 & 4.90839 \\
Beban Kerja & 40 & 21.00 & 37.00 & 30.8000 & 3.96911 \\
$\begin{array}{l}\text { Kualitas Penyajian } \\
\text { Keuangan }\end{array}$ & Laporan40 & 42.00 & 55.00 & 48.0750 & 3.60475 \\
\hline
\end{tabular}

Sumber: Data Penelitian, 2020

Berdasarkan Tabel 1, dapat disimpulkan bahwa jumlah pengamatan $(\mathrm{N})$ penelitian ini berjumlah 40. Variabel kompetensi memiliki nilai minimum sebesar 43.00 dan nilai maksimum sebesar 60.00 dengan nilai rata-rata sebesar 50.9000. Standar deviasi pada variabel kompetensi adalah sebesar 4.90839, hal ini menunjukkan bahwa standar penyimpangan data pada nilai rata-ratanya adalah 4.90839 . 
Variabel beban kerja memiliki nilai minimum sebesar 21.00 dan nilai maksimum sebesar 37.00 dengan nilai rata-rata sebesar 30.8000. Standar deviasi pada variabel kompetensi adalah sebesar 3.96911, hal ini menunjukkan bahwa standar penyimpangan data pada nilai rata-ratanya adalah 3.96911.

Variabel kompetensi memiliki nilai minimum sebesar 42.00 dan nilai maksimum sebesar 55.00 dengan nilai rata-rata sebesar 48.0750. Standar deviasi pada variabel kompetensi adalah sebesar 3.60475, hal ini menunjukkan bahwa standar penyimpangan data pada nilai rata-ratanya adalah 3.60475.

Penelitian ini menggunakan analisis regresi linear berganda untuk mengetahui atau memperoleh gambaran mengenai pengaruh variabel bebas pada variabel terikat. Analisis ini dilakukan dengan menggunakan bantuan software SPSS 18.0 for Windows. Adapun hasil analisis regresi linear berganda dapat dilihat pada Tabel 2, sebagai berikut.

\section{Tabel 2. Regresi Linier Berganda}

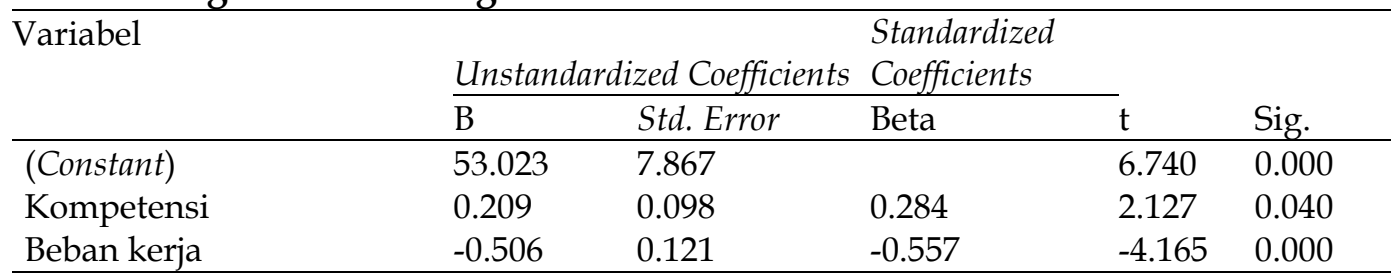

Sumber: Data Penelitian, 2020

Berdasarkan hasil analisis regresi linier berganda seperti yang disajikan pada Tabel 2, maka dapat dibuat persamaan regresi sebagai berikut:

$$
Y=53,023+0,209 X_{1}-0,506 X_{2}
$$

Nilai koefisien regresi masing-masing variabel bebas memiliki nilai signifikansi uji $t$ kurang dari 0,05. Hal ini menunjukkan bahwa semua variabel bebas memiliki pengaruh yang signifikan terhadap variabel terikat.

Uji statistik F dilakukan untuk mengetahui apakah semua variabel bebas yang diidentifikasi (kompetensi, dan beban kerja) tepat digunakan memprediksi kualitas penyajian laporan keuangan secara bersama-sama. Uji ini sering juga disebut dengan uji F. Adapun hasil uji F dalam penelitian ini dapat dilihat pada Tabel 3, sebagai berikut.

\section{Tabel 3. Hasil Uji F}

\begin{tabular}{llllll}
\hline Model & Sum of Squares & df & Mean Square & F & Sig. \\
\hline Regression & 295.917 & 2 & 147.959 & 25.963 & $0.000^{\mathrm{a}}$ \\
Residual & 210.858 & 37 & 5.699 & & \\
Total & 506.775 & 39 & & & \\
\hline
\end{tabular}

Sumber: Data Penelitian, 2020

Hasil uji $\mathrm{F}$ (Ftest) menunjukkan bahwa nilai signifikansi $\mathrm{P}$ value 0,000 yang lebih kecil dari $a=0,05$, ini berarti model yang digunakan pada penelitian ini adalah layak. Hasil ini memberikan makna bahwa seluruh variabel independen mampu memprediksi atau menjelaskan fenomena kualitas penyajian laporan keuangan. Dengan kata lain ada pengaruh secara simultan dari variabel kompetensi, dan beban kerja terhadap kualitas penyajian laporan keuangan. Hal ini berarti model dapat digunakan untuk analisa lebih lanjut atau dengan kata lain model dapat digunakan untuk memproyeksikan karena hasil goodness of fitnya baik dengan nilai signifikansi P value 0,000. 
Koefisien determinasi $\left(\mathrm{R}^{2}\right)$ digunakan untuk mengetahui dan mengukur kemampuan model dalam menerangkan variasi variabel independen. Peneliti menggunakan nilai adjusted $\mathrm{R}^{2}$ pada saat mengevaluasi yang mana model regresi terbaik, karena tidak seperti $\mathrm{R}^{2}$, nilai adjusted $\mathrm{R}^{2}$ dapat naik atau turun apabila satu variabel independen ditambahkan ke dalam model. Adapun hasil uji koefisien determinasi $\left(R^{2}\right)$ dalam penelitian ini dapat dilihat pada Tabel 4, sebagai berikut.

Tabel 4. Hasil Uji Koefisien Determinasi

\begin{tabular}{llllllr}
\hline Model & & S Square & Adjusted R Square & $\begin{array}{l}\text { Std. Error of the } \\
\text { Estimate }\end{array}$ & \\
\hline 1 & $0.764^{\mathrm{a}}$ & 0.584 & 0.561 & 2.38723 & \\
\hline
\end{tabular}

Sumber: Data Penelitian, 2020

Berdasarkan pada Tabel 4, menunjukkan hasil dimana diperoleh besarnya adjusted $\mathrm{R}^{2}$ (koefisien determinasi yang telah disesuaikan) adalah sebesar 0,561. Ini berarti variasi kualitas penyajian laporan keuangan dapat dipengaruhi secara signifikan oleh variabel kompetensi, dan beban kerja sebesar 56,1 persen, sedangkan sisanya sebesar 43,9 persen dijelaskan oleh faktor-faktor lain yang tidak dijelaskan dalam model penelitian.

Berdasarkan hasil analisis pengaruh kompetensi terhadap kualitas penyajian laporan keuangan diperoleh nilai signifikasi sebesar 0,040 dengan nilai koefisien regresi positif sebesar 0,209. Nilai signifikansi $0,040<0,05$ mengindikasikan bahwa $\mathrm{H}_{1}$ diterima. Hasil ini mempunyai arti bahwa kompetensi berpengaruh positif dan signifikan terhadap kualitas penyajian laporan keuangan. Artinya semakin tinggi kompetensi yang dimiliki pegawai, maka kualitas penyajian laporan keuangan yang dihasilkan akan semakin meningkat.

Berdasarkan hasil analisis pengaruh beban kerja terhadap kualitas penyajian laporan keuangan diperoleh nilai signifikansi sebesar 0,000 dengan nilai koefisien regresi negatif sebesar -0,506. Nilai signifikansi $0,000<0,05$ mengindikasikan bahwa $\mathrm{H}_{2}$ diterima. Hasil ini mempunyai arti bahwa beban kerja berpengaruh negatif dan signifikan terhadap kualitas penyajian laporan keuangan. Artinya beban kerja yang tinggi akan membuat kualitas penyajian laporan keuangan semakin menurun.

Berdasarkan hasil perhitungan yang ditunjukkan pada Tabel 4, diketahui bahwa tingkat signifikansi t uji satu sisi sebesar 0,040 yang berarti lebih kecil dari $\mathrm{a}=0,05$. Hal ini menunjukkan bahwa hipotesis pertama $\left(\mathrm{H}_{1}\right)$ yaitu semakin tinggi kompetensi yang dimiliki akan meningkatkan kualitas penyajian laporan keuangan di UPT Kementerian Lingkungan Hidup dan Kehutanan Provinsi Bali diterima. Kompetensi yang dimiliki memang tergolong tinggi karena adanya pelatihan yang diikuti oleh pegawai dan dari keterampilan yang dinyatakan dalam pelaksanaan tugas yang berhubungan dengan akuntansi dan pengelola keuangan. Dengan adanya kompetensi maka waktu penyusunan laporan keuangan dapat efektif dan efisien, karena sumber daya manusia tersebut telah memiliki pengetahuan dan pemahaman mengenai hal-hal yang dikerjakan sehingga laporan keuangan yang disusun dapat diselesaikan dan disajikan tepat pada waktunya. Oleh karena itu laporan keuangan pemerintah pusat Kementerian Lingkungan Hidup dan Kehutanan, selama 2 tahun anggaran 
terakhir yakni tahun anggaran 2017 dan 2018 memperoleh opini dari pihak Badan Pemeriksa Keuangan Republik Indonesia menyatakan Opini Wajar Tanpa Pengecualian (WTP). Hasil penelitian ini selaras dengan penelitian yang dilakukan oleh Irwan (2011) yang menemukan bahwa kompetensi berpengaruh positif terhadap kualitas LKPD dan penelitian (Rahman et al., 2012) yang menemukan bahwa kompetensi, pelatihan dan SAI berpengaruh positif terhadap kualitas laporan keuangan. Dengan demikian semakin kompeten sumber daya manusia penyusun laporan keuangan, maka semakin baik kualitas penyajian laporan keuangan yang dihasilkan.

Berdasarkan hasil perhitungan yang ditunjukkan pada Tabel 4, diketahui bahwa tingkat signifikansi $t$ uji satu sisi sebesar 0,000 yang berarti lebih kecil dari $a=0,05$. Hal ini menunjukkan bahwa hipotesis kedua $\left(\mathrm{H}_{2}\right)$ yaitu semakin tinggi beban kerja akan menurunkan kualitas penyajian laporan keuangan di UPT Kementerian Lingkungan Hidup dan Kehutanan Provinsi Bali diterima. Apabila beban kerja penyusun laporan keuangan terlalu tinggi akibatnya tugasnya dalam menyelesaikan dan menyajikan laporan keuangan tidak tepat pada waktunya, hal ini akan mempengaruhi penurunan kualitas penyajian laporan keuangan. Tingginya beban kerja penyusun laporan keuangan tersebut juga dapat mempengaruhi sikap dan perilakunya seperti kurang konsentrasi, kelelahan dan jenuh dalam bekerja. Beban kerja yang berlebihan akan menimbulkan kelelahan fisik dan psikis yang akan berdampak negatif seperti kualitas kerja menurun dan kenaikan tingkat absensi. Oleh karena itu Kementerian Lingkungan Hidup dan Kehutanan mendapat opini Wajar Dengan Pengecualian (WDP) pada tahun anggaran 2015 dan 2016 yang sebelumnya pada tahun anggaran 2014 mendapat opini WTP dari hasil pemeriksaan laporan keuangan oleh BPK RI. Hal tersebut dikarenakan pada tahun 2015 terjadi penggabungan dua kementerian antara Kementerian Lingkungan Hidup dan Kementerian Kehutanan, sehingga menyebabkan beban kerja yang ditimbulkan cukup tinggi. Hasil penelitian ini selaras dengan penelitian yang dilakukan oleh Setiawan \& Fitriany (2011) beban kerja yang dikaitkan dengan beban kerja profesi auditor yang hasilnya menunjukkan beban kerja terbukti berpengaruh negatif terhadap kualitas audit dan penelitian oleh Nasution (2012) menyatakan bahwa beban kerja berpengaruh negatif terhadap peningkatan kemampuan auditor dalam mendeteksi gejalagejala kecurangan dikarenakan beban kerja yang berlebihan.

\section{SIMPULAN}

Penelitian ini memberikan tambahan informasi mengenai bagaimana kompetensi dan beban kerja operator SAI mempengaruhi kualitas penyajian laporan keuangan pemerintah pusat. Untuk lebih meningkatkan kompetensi operator SAI yaitu dengan meningkatkan keterlibatan operator SAI dalam pelatihan tentang pengelolaaan keuangan pemerintah. Beban kerja operator SAI sebagai penyusun laporan keuangan perlu diperhatikan agar kualitas penyajian laporan keuangan tersebut relevan, andal, dapat dipahami dan dapat dibandingkan. Dalam penelitian selanjutnya diharapkan dapat menambah metode pengambilan data misalnya dengan observasi dan wawancara sehingga dapat meningkatkan kualitas data, memperbesar jumlah sampel yang diteliti, serta mempertimbangkan variabel-variabel lain yang diduga berpengaruh pada 
kualitas penyajian laporan keuangan, seperti sistem pengendalian intern dan pengalaman kerja aparatur, pemanfaatan teknologi yang belum dimasukkan dalam penelitian ini.

Berdasarkan hasil penelitian dan simpulan di atas maka saran yang dapat diberikan yaitu diharapkan pemerintah pusat untuk mengadakan pelatihanpelatihan secara berkesinambungan agar pemahaman mengenai akuntansi dapat lebih ditingkatkan seiring dengan berkembangnya zaman, karena latar belakang disiplin ilmu aparatur yang berbeda. Pengelolaan beban kerja yang baik dan pembagian job description yang disesuaikan dengan kompetensi operator SAI tersebut dapat meminimalkan beban kerja operator SAI. Untuk tetap menjaga kualitas penyajian laporan keuangan para kepala kantor di unit-unit kerja dapat menambah jumlah pegawai di bidang keuangan khususnya unit kerja yang penyusun laporan keuangannya yang masih merangkap pekerjaannya.

\section{REFERENSI}

Adha Inapty, M. A. F. B., \& Martiningsih, R. S. P. (2016). Pengaruh Penerapan Standar Akuntansi Pemerintah, Kompetensi Aparatur dan Peran Audit Internal Terhadap Kualitas Informasi Laporan Keuangan dengan Sistem Pengendalian Intern Sebagai Variabel Moderating (Studi Empiris pada SKPD di Pemprov NTB). Akuntabilitas, 9(1), 27-42. https://doi.org/10.15408/akt.v9i1.3583

Amin, A. M. (2011). Pengaruh Kompetensi dan Sistem Akuntansi Instansi Terhadap kualitas Pertanggungjawaban Laporan Keuangan Pada Unit Pelaksana Teknis (UPT) Kementerian Pendidikan Nasional Provinsi Sumatera Utara. Universitas Sumatera Utara.

Asdyanti, R. (2012). Analisis Hubungan Beban Kerja dan Kinerja Karyawan Departemen Contract Category Management di Chevron Indoasia Business Unit. Universitas Indonesia.

Beest, F. Van, Braam, G., \& Suzanne, B. (2009). Quality of financial reporting: measuring qualitative characteristics NiCE Working Paper 09-108 Quality of Financial Reporting: measuring qualitative characteristics. In Nijmegen Center for Economics (NiCE). http:/ / www.ru.nl/nice/workingpapers

Caers, R., Du Bois, C., Jegers, M., De Gieter, S., Schepers, C., \& Pepermans, R. (2006). Principal-agent relationships on the stewardship-agency axis. Nonprofit Management and Leadership. https://doi.org/10.1002/nml.129

David M. (2006). Agents or stewards: Using theory to understand the government-nonprofit social service contracting relationship. Journal of Public Administration Research and Theory, 17. https://doi.org/10.1093/jopart/mul012

Davis, J. H., Schoorma, F. D., \& Donaldson, L. (1997). Towards a stewardship theory of management. Academy of Management Review, 22(3), 20-47.

Davis, J.H., Schoorman, D.L. and Donaldson, L. (1997). The Distinctiveness of Agency Theory and Stewardship Theory. Academy of Management Review, 22, 611-613.

Fahriani, M. S. (2015). Pengaruh Workload dan Spesialisasi Auditor terhadap Kualitas Audit (Studi Kasus Pada Auditor Di KAP Big Four). Jurnal Ilmiah Universitas Bakrie, 3(2). 
FASB. (2008). Financial Accounting Series, Statement of Financial Accounting Standards, Exposure Draft: Conceptual Framework for Financial Reporting: The Objective of Financial Reporting and Qualitative Characteristics and Constraints of Decision-Useful Financial Repor. Norwalk, No. 1570-100.

Fathurrahman, M. (2019). Pengaruh Kompetensi, Beban Kerja Operator Sistem Akuntansi Instansi (SAI) dan Penerapan Standar Akuntansi Pemerintah (SAP) terhadap Kualitas Penyajian Laporan Keuangan Pada Kantor Pelayanan Perbendaharaan Negara (KPPN) Palembang Provinsi Sumatera Selatan. Politeknik Negeri Sriwijaya.

Ghozali, I. (2018). Aplikasi Analisis Multivariate dengan Program IBM SPSS 25. In (Edisi 9). Semarang: Badan Penerbit Universitas Diponegoro.

Han, J., Chou, P., Chao, M., \& Wright, P. M. (2006). The HR competencies and HR effectiveness link: A study in Taiwanese high and tech companies. Human Resource Management, 45(3), 391-406.

Hevesi, G. A. (2005). Standart for Internal Control in New York State Government. Jakarta.

Hutapea \& N. Thoha. (2008). Kompetensi Plus. Gramedia Pustaka Utama.

Irwan, D. (2011). Pengaruh Penerapan SPIP, Kompetensi SDM dan Penerapan SAP terhadap Kualitas Laporan Keuangan Pemerintah Provinsi Sumatera Barat. Universitas Negeri Padang.

Keputusan Kepala Badan Kepegawaian Negeri Nomor 46A Tahun 2003 tentang Pedoman Penyusunan Standar Kompetensi Jabatan Struktural Pegawai Negeri Sipil

Lopez-Acevedo, D. M. (2005). The Effect Of Workload Comperenssion On Audit Quality.

Manopo, C. (2011). Competency Based Talent and Performance Management System. Salemba Empat.

Manuaba, A. (2000). Ergonomi, Kesehatan dan Keselamatan Kerja. In Eds. Proceedings Seminar Nasional Ergonomi (hal. 1-4). PT. Guna Widya.

Mardiasmo. (2002). Akuntansi Sektor Publik. In Yogyakarta: Andi.

Mei Anggreni, N. M. (2018). Pengaruh Good Governance dan Kompetensi Sumber Daya Manusia pada Kualitas Laporan Keuangan di Kota Denpasar (Vol. 22) [Universitas https://doi.org/https://doi.org/10.24843/EJA.2018.v22.i01.p14

Menteri Pendayagunaan Aparatur Negara. (1997). Definisi Beban Kerja. http://www.bkn.go.id

Morgan, D., Bacon, K. G., Bunch, R., Cameron, C. D., \& Deis, R. (1996). What Middle Managers Do in Local Government: Stewardship of the Public Trust and the Limits of Reinventing Government. Public Administration Review. https://doi.org/10.2307/976377

Nasution, H. (2012). Pengaruh Beban Kerja, Pengalaman Audit dan Tipe Kepribadian terhadap Skeptisme Profesional dan Kemampuan Auditor dalam Mendeteksi Kecurangan. Universitas Islam Negeri Syarif Hidayatullah.

Nordiawan, D., Sondi Putra, I., \& Rahmawati, M. (2007). Akuntansi Pemerintahan (Kedua). Salemba Empat.

O’Donnell, R. D., \& Eggemeier, F. T. (1986). Workload Assessment Methodology.

Peraturan Pemerintah No. 101 Tahun 2000 Tentang Pendidikan dan Pelatihan 
Jabatan Pegawai Negeri Sipil

Peraturan Pemerintah No 71 Tahun 2010 Tentang Standar Akuntansi Pemerintahan, 1 (2010). https:/ / doi.org/10.1017/CBO9781107415324.004

PMK No.210/PMK.05/2013 Pedoman Rekonsiliasi Dalam Rangka Penyusunan Lap. Keuang. Lingkup Bendahara Umum Negara dan Kementerian/Lembaga.

Podrug, N. (2011). The Strategic Role Of Managerial Stewardship Behaviour For Achieving Corporate Citizenship. Ekonomski Pregled, 62(7-8), 404-420.

Rahman, A., Darwanis, \& Siswar, D. (2012). Pengaruh Kompetensi, Pelatihan dan Sistem Akuntansi Instansi terhadap Kualitas Pertanggungjawaban Laporan Keuangan Dana Dekonsentrasi. Jurnal Akuntansi Pascasarjana Universitas Syiah Kuala.

Reid, G. B., \& Nygren, T. E. (1988). The Subjective Workload Assessment technique: a scaling procedure for measuring mental workload. In P. A. Hancock and N. Meshkati (eds). Human Mental Workload. Advances in Psychology, 52, 185-218. https:// doi.org/10.1016/S0166-4115(08)62387-0

Sari, L. I. N., \& Suaryana, I. G. N. A. (2014). Pengaruh Kualitas Laporan Keuangan Pada Efisiensi Investasi Perusahaan Pertambangan. E- Joural Akuntansi Universitas Udayana, 8(3), 524-537.

Sarjono, H., \& Julianita, W. (2011). SPSS vs LISREL: Sebuah Pengantar, Aplikasi untuk Riset. Salemba Empat.

Setiawan, L., \& Fitriany, F. (2011). Pengaruh Workload Dan Spesialisasi Auditor Terhadap Kualitas Audit Dengan Kualitas Komite Audit Sebagai Variabel Pemoderasi. Jurnal Akuntansi dan Keuangan Indonesia, 8(1), 36-53. https://doi.org/10.21002/jaki.2011.03

Slyke, V. (2006). Agents or Stewards: Using Theory to Understand the Government-Nonprofit Social Service Contracting Relationship. Journal of Public Administration Research and Theory, 17(5), 157-187.

Soimah, S. (2014). Pengaruh Kapasitas Sumber Daya Manusia, Pemanfaatan Teknologi Informasi dan Sistem Pengendalian InternPemerintah Daerah terhadap Kualitas Laporan Keuangan Pemerintah Daerah Kabupaten Bengkulu Utara. Universitas Bengkulu.

Sugiyono. (2015). Metode Penelitian Bisnis. In Bandung: Alfabeta.

Suma'mur, P. K. (1995). Higiene Perusahaan dan Kesehatan Kerja. PT Toko Gunung Agung.

Thornton, D. D. (2009). Stewardship in Government Spending:Accountability,Transparency, Earmarks, and Competition. Public Interest Institute, 9(1).

Undang-Undang Nomor 7 Tahun 2013 Tentang Pedoman Penyusunan Standar Kompetensi Manjerial Pegawai Negeri Sipil.

Utama, M. S. (2016). Buku Ajar Aplikasi Analisis Kuantitatif. In Journal of Visual Languages \& Computing (Keenam, Vol. 11, Nomor 3).

Vargas, S. A. (2004). Development of Corporate Governance Systems : Agency Theory Versus Stewardship Theory in Welsh Agrarian Cooperative Societies Development of Corporate Governance Systems: Agency Theory. http://www.uhu.es/alfonso_vargas/archivos/EURAM\%202004.pdf: Retrieved on 8 May, 2014, 1997, 1-20. 
Wilson, K. R., Div, M., \& Seminary, D. (2010). Steward Leadership : Characteristics of the Steward Leader in Christian Nonprofit Organizations. 1-190.

Winaya, K. (1989). Manajemen Sumber Daya Manusia (Lanjutan) (Ketiga). Fakultas Ekonomi Universitas Udayana.

www.menlhk.go.id. Kementerian Lingkungan Hidup dan Kehutanan. Diakses 16 Juli 2019, dari https://www.menlhk.go.id/

Yuneita Anisma, A. H. dan S. (2014). Pengaruh Kompetensi Sumber Daya Manusia, Penerapan Sistem Akutansi Keuangan Daerah dan Sistem pengendalian Intern terhadap Kualitas Laporan Keuangan Pemerintah Daerah Studi Empiris pada SKPD Kabupaten Kuantan Singingi. In JOM FEKOM (Vol. 1). Universitas Riau. 